\title{
Hyperbaric oxygenation upregulates rat lung $\mathrm{Na}$,K-ATPase
}

\author{
Z.L. Harris*, K.M. Ridge+, B. Gonzalez-Flecha+, L. Gottlieb**, \\ A. Zucker*, J.I. Sznajder ${ }^{+}$
}

\begin{abstract}
Hyperbaric oxygenation upregulates rat lung Na,K-ATPase. Z.L. Harris, K.M. Ridge, B. Gonzalez-Flecha, L. Gottlieb, A. Zucker, J.I. Sznajder. CERS Journals Ltd 1996.

ABSTRACT: Exposure of rats to hyperoxia is associated with increased active $\mathrm{Na}^{+}$transport in rat lungs and increased $\mathrm{Na}, \mathrm{K}$-adenosine triphosphate (ATPase) expression in alveolar epithelial cells. Hyperbaric oxygenation (HBO) has been reported to act as an accelerated model of hyperoxic cell damage. Sublethal and intermittent exposure to $\mathrm{HBO}$, however, has been suggested to upregulate endogenous protective mechanisms.

In the present study, we tested whether short-term HBO, prior to inducing lung injury, would upregulate lung Na,K-ATPase.

The results show that $\mathrm{HBO}$, either intermittent or single $2.5 \mathrm{~h}$ exposure, increased lung Na,K-ATPase $\alpha-1$ and $\beta-1$ messenger ribonucleic acid (mRNA) transcript levels up to fourfold. Na,K-ATPase activity in lungs of rats exposed to HBO increased twofold during the first $\mathbf{2} \mathrm{h}$ following removal from the hyperbaric chamber, and remained elevated for up to $6 \mathrm{~h}$ following HBO.

Conceivably, the increase in Na,K-ATPase activity following $\mathrm{HBO}$ is due to an increase in activity from a basal to a higher rate, or possibly due to recruitment/translocation of Na,K-ATPases from inner membranes to the plasma membrane. Eur Respir J., 1996, 9, 472-477.
\end{abstract}

+Pulmonary and Critical Care Medicine, Michael Reese Hospital and University of Illinois at Chicago, Chicago, IL, USA. *Pediatric Critical Care and **Surgery Departments, University of Chicago, Chicago, IL, USA.

Correspondence: J.I. Sznajder, Michael Reese Hospital, Pulmonary and Critical Care Medicine, 2929 S. Ellis Avenue, RC 216, Chicago, IL 60616, USA

Keywords: Alveolar Na,K-ATPase, hyperbaric oxygenation, lung injury

Received: November 221994

Accepted after revision November 221995

This study was supported in part by a Pediatric Fellowship Award from the American Lung Association (ZLH), a Career Investigator Award from the American Lung Association (JIS), the Winfield Fund and the Michael Reese Health Trust.
Normobaric hyperoxia and hyperbaric oxygen (HBO) exposure have been shown to increase reactive oxygen species and cause lung injury [1-3]. Hyperbaric oxygen causes an accelerated pulmonary oxygen toxicity [4]. HARABIN et al. [5] showed that hyperbaric oxygen $(2.8$ ATA, $100 \%$ oxygen) was lethal both to rats and guineapigs when exposed continuously for 5-12 h, but that intermittent exposure conferred protection [5]. They observed that intermittent HBO slowed ongoing oxidative damage and they postulated that tolerance was due to upregulation of endogenous protective mechanisms.

We have previously observed that rats exposed to $85 \%$ oxygen for 7 days exhibited increased active $\mathrm{Na}^{+}$transport across the lung epithelium, as well as increased $\mathrm{Na}, \mathrm{K}$ adenosine triphosphate (ATPase) protein function in the alveolar epithelium [6]. Our previous study in the normobaric hyperoxia model and others [7], suggest that upregulation of the $\mathrm{Na}, \mathrm{K}$-ATPase in rat lungs are part of the protective mechanism against alveolar flooding.

In the present study, we postulated that short-term HBO would upregulate rat lung $\mathrm{Na}, \mathrm{K}-\mathrm{ATPase}$. The scope of this investigation was to determine whether short-term HBO exposure, either as a single $2.5 \mathrm{~h}$ dose, or as a $2.5 \mathrm{~h}$ dose following intermittent $\mathrm{HBO}$ exposure would result in upregulation of a protective mechanism against lung oedema, namely alveolar Na,K-ATPase. The HBO exposure dose was specifically chosen to be sublethal. Previously, it had been shown that exposure of rats to greater than $5 \mathrm{~h}$ of HBO caused both cerebral and pulmonary oedema [5]. To test this hypothesis, we measured steady- state $\mathrm{Na}, \mathrm{K}-\mathrm{ATPase}$ messenger ribonucleic acid (mRNA) transcript levels, Na,K-ATPase hydrolytic activity in rat lung homogenates and $\mathrm{Na}, \mathrm{K}$-ATPase protein expression by immunohistochemical analysis in lung sections from rats exposed to $\mathrm{HBO}$. We found that $\mathrm{HBO}$ increased steadystate $\mathrm{Na}, \mathrm{K}$-ATPase $\alpha-1$ and $\beta-1$ mRNA transcripts and $\alpha-1 \mathrm{Na}, \mathrm{K}-\mathrm{ATPase}$ protein in rat lungs, as well as $\mathrm{Na}, \mathrm{K}-$ ATPase activity, as compared to lungs from control rats. These findings support our hypothesis that short-term HBO upregulates rat alveolar $\mathrm{Na}, \mathrm{K}-\mathrm{ATPase}$.

\section{Materials and methods}

\section{Experimental protocol}

Twenty eight adult, male, pathogen-free, SpragueDawley rats (weighing 200-250 g; Charles River Laboratories) were studied. Animals were maintained on a $12 \mathrm{~h}$ light/dark cycle. Rats were exposed to $100 \%$ oxygen at 2.8 ATA hyperbaric pressure within a hyperbaric chamber for small animals (Model B-11; REI Scientific, Alexandria, VA, USA). Rates of compression and decompression were kept constant over 10 min each. The chamber was kept at $18-20^{\circ} \mathrm{C}$. Control rats were maintained in room air.

The animals were divided into three groups: Group 1 $(n=12)$ was exposed to 2.8 ATA HBO for a single $2.5 \mathrm{~h}$ exposure; Group $2(\mathrm{n}=12)$ was pre-exposed to $3 \times 1.5 \mathrm{~h}$ 2.8 ATA $\mathrm{HBO}$ at $24 \mathrm{~h}$ intervals, followed by a single 2.5 h HBO exposure; and Group $3(n=4)$ were room air 
controls. Animals were studied immediately upon removal from the HBO chamber and at 1,2 and $6 \mathrm{~h}$ following HBO exposure ( $n=3$ at each time-point).

Ten minutes prior to euthanasia, the animals received $1,000 \mathrm{U}$ of heparin, followed by sodium pentobarbital (30 $\mathrm{mg} \cdot \mathrm{kg}^{-1}$ body weight), both intraperitoneally. After validation of adequate anaesthesia, a mid-line thoracoabdominal incision was made, and the animals exsanguinated by renal artery and vein laceration. The trachea was cannulated and the heart and lungs removed en bloc. The right upper lobe was ligated and excised for wet/dry weight determination. The pulmonary artery was cannulated and the lungs were perfused and subsequently lavaged with buffered saline solutions (Solution No. 1 in mM: $140 \mathrm{NaCl}, 5 \mathrm{KCl}, 2.5 \mathrm{NaH}_{2} \mathrm{PO}_{4}, 6$ glucose, 0.2 ethylene glycol tetra-acetic acid (EGTA), and 10 hydroxyethylpiperazine ethanesulphonic acid (HEPES); Solution No. 2: $140 \mathrm{NaCl}, 5 \mathrm{KCl}, 2.5 \mathrm{Na}_{2} \mathrm{HPO}_{4}, 2 \mathrm{CaCl}_{2}, 1.3$ $\mathrm{MgSO}_{4}$ and 10 HEPES).

\section{Wet/dry weight determination}

The right upper lobe was ligated, excised prelavage, weighed (wet weight) and dried under vacuum (Speed Vac SC100; Savant Instruments, Farmingdale, NY, USA). After drying, the lung sample was reweighed (dry weight) and the wet/dry weight ratio calculated.

\section{Ribonucleic acid (RNA) isolation and Northern analysis}

Lung tissue recovered for RNA analysis was immediately placed into liquid nitrogen and stored at $-70^{\circ} \mathrm{C}$. Later it was thawed and homogenized (Kinematica $\mathrm{GmBH}$ homogenizer, Switzerland) in 5.2 M guanidine thiocyanate. After extraction with phenol/chloroform [8], the RNA was precipitated with ethanol and collected by centrifugation. Quantification and purity were determined spectrophotometrically.

Five micrograms of total RNA was loaded per lane and size fractionated in a $1 \%$ agarose- $2.2 \mathrm{M}$ formaldehyde gel in $1 \times 3-(\mathrm{N}$-morpholino)propane sulphonic acid (MOPS) buffer. Integrity and equal lane loading was confirmed by staining with ethidium bromide $\left(0.5 \mu \mathrm{g} \cdot \mathrm{mL}^{-1}\right)$. RNA was electrotransferred from the gel to a nylon membrane (S\&S Nytran, Midwest Scientific) in $1 \times$ Tris acetate buffer: $0.04 \mathrm{M}$ Tris acetate, $0.001 \mathrm{M}$ EDTA (TAE) over $6 \mathrm{~h}$ at $20 \mathrm{~V}$ and covalently cross-linked to the membrane by ultra violet (UV) fixation (366 nm, Hoefer Scientific Instruments, San Francisco, CA, USA) for 5 min, followed by baking at $80^{\circ} \mathrm{C}$ for $2 \mathrm{~h}$. Membranes were hybridized to ${ }^{32} \mathrm{P}$-labelled rat Na,K-ATPase complementary ribonucleic acid (cRNA) probes. The $\alpha-1$ $\mathrm{Na}, \mathrm{K}-\mathrm{ATP}$ ase cRNA probe was a $1.0 \mathrm{~kb} \mathrm{cRNA}$ encoding the 5 ' end of the $\alpha-1$ subunit, and the $\beta-1 \mathrm{Na}, \mathrm{K}$-ATPase cRNA probe was a $1.0 \mathrm{~kb}$ full length $\beta-1$ subunit cRNA. cRNA probes were prepared for the $\alpha-1$ and $\beta-1 \mathrm{Na}, \mathrm{K}-$ ATPase subunits from complementary deoxyribonucleic acids (cDNAs) (a generous gift from J. Emmanuel) subcloned into pGEM3Z (Promega). The cDNA jun probe was $2.5 \mathrm{~kb}$ (a generous gift from V. Sukhatme).

Membranes were prehybridized at $57^{\circ} \mathrm{C}$ in $50 \%$ formamide, $250 \mu \mathrm{g} \cdot \mathrm{mL}^{-1}$ sheared salmon sperm DNA, 250 $\mu \mathrm{g} \cdot \mathrm{mL}^{-1}$ yeast RNA, $1 \%$ sodium dodecyl sulphate (SDS), and $5 \times$ standard sodium citrate (SSC) for $3 \mathrm{~h}$, after which either probe was added and the incubation continued for an additional $18 \mathrm{~h}$. After hybridization, the membranes were washed in $2 \times \mathrm{SSC}-1 \% \mathrm{SDS}$ at $68^{\circ} \mathrm{C}$ three times, followed by $0.1 \times \mathrm{SSC}-1 \% \mathrm{SDS}$ at $60^{\circ} \mathrm{C}$ three times. Bands were visualized by autoradiography. The autoradiograms were quantified by density scanning (Hoeffer Scientific GS300, San Francisco, CA, USA). $\alpha-1 \mathrm{Na}, \mathrm{K}-$ ATPase mRNA transcript level was normalized to the $18 \mathrm{~S}$ rRNA of the same sample (American Type Culture Collection, Rockville, MD, USA). Final RNA density was normalized, such that the room air control value was designated 1 unit.

\section{Na,K-ATPase hydrolytic activity}

Rat lung homogenates were prepared in a sucrose/imidazole buffer $\left(\mathrm{pH} 7.4,4^{\circ} \mathrm{C}\right)$ using a Teflon homogenizer (Barnant-Series 10; Barrington, IL, USA) and the fresh homogenate was filtered through two layers of gauze. Na,K-ATPase activity was determined in $100 \mu \mathrm{L}$ aliquots of fresh homogenate in the presence and absence of $2 \mathrm{mM}$ ouabain. The results were corrected for spontaneous hydrolysis of adenosine triphosphate (ATP). A measure of ouabain-sensitive $\mathrm{Na}, \mathrm{K}$-ATPase activity was estimated by determining the ouabain-inhibitable portion of the ATPase activity [9]. Inorganic phosphate was measured spectrophotometrically by the method of FISKE and Subbarow [10]. The specific activity of the $\mathrm{Na}, \mathrm{K}-$ ATPase is expressed as $\mu \mathrm{mol}$ inorganic phosphate $(\mathrm{Pi}) \cdot \mathrm{mg}^{-1}$ protein $\cdot h^{-1}$. Protein was determined by the method of LOWRY et al. [11].

\section{Immunohistochemical localization}

The Na,K-ATPase was localized in rat lungs by immunogold silver staining of thin sections of lung tissue (AuroProbe®TM LM; Amersham International). Briefly, tissue samples $(5 \mu \mathrm{m}$ thick) were fixed on slides and incubated in nonimmune goat serum for $20 \mathrm{~min}$ and then overnight with an immunopurified, subunit and species specific, polyclonal primary antibody (rabbit anti-rat) directed against the $\alpha-1$ subunit of the Na,K-ATPase (purchased from Upstate Biotechnology Institute, [12]). Immunodetection with gold-conjugated secondary antibodies (goat anti-rabbit, Amersham International) was aided by a silver enhancement process, followed by haematoxylin and eosin staining.

\section{Statistical analysis}

One way analysis of variance and Duncan's comparison test were used for statistical analysis. Assuming a normal distribution, results were considered significant when p-value was less than 0.05 .

\section{Results}

Grossly, the lungs from both groups of animals did not appear injured. As shown in figure 1, the wet/dry weight determinations from exposed rats were similar to the room air control animals (room air control 4.9 \pm 0.3 ; 


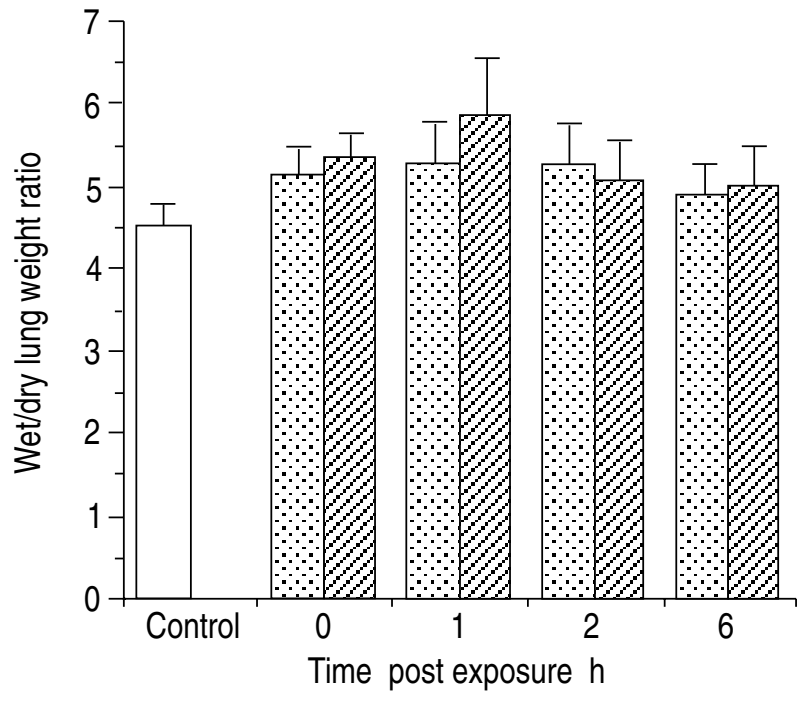

Fig. 1. - Rat lung wet/dry weight ratios after hyperbaric oxygen (HBO) exposure. The figure shows ratios from control lungs (not exposed to HBO), lungs after a single $2.5 \mathrm{~h} \mathrm{HBO}$ exposure ( $\because \because$ ), and lungs after intermittent $\mathrm{HBO}(\square)$. Data are presented as mean \pm SEM. intermittent $\mathrm{HBO} 5.1 \pm 0.4$; single HBO 5.2 \pm 0.4 ), and the values are consistent with absence of lung oedema.

Steady-state levels of Na,K-ATPase $\alpha-1$ mRNA transcripts in the single HBO exposure group were elevated fourfold at 0 and $1 \mathrm{~h}$, as compared to control values, and twofold over control value at $6 \mathrm{~h}$ (fig. 2). In the intermittent HBO pre-exposed group, the Na,K-ATPase $\alpha-1 \mathrm{mRNA}$ transcripts increased fourfold, peaking at $2 \mathrm{~h}$, following the $2.5 \mathrm{~h} \mathrm{HBO}$ exposure and persisting at a twofold increase at $6 \mathrm{~h}$, as compared to controls.

Steady-state Na,K-ATPase $\beta$-1 subunit mRNA transcripts were fourfold higher in the HBO pre-exposed group as compared to room air controls at $0 \mathrm{~h}$ and returned to control level by $2 \mathrm{~h}$ (fig. 3 ). In the single $2.5 \mathrm{~h}$

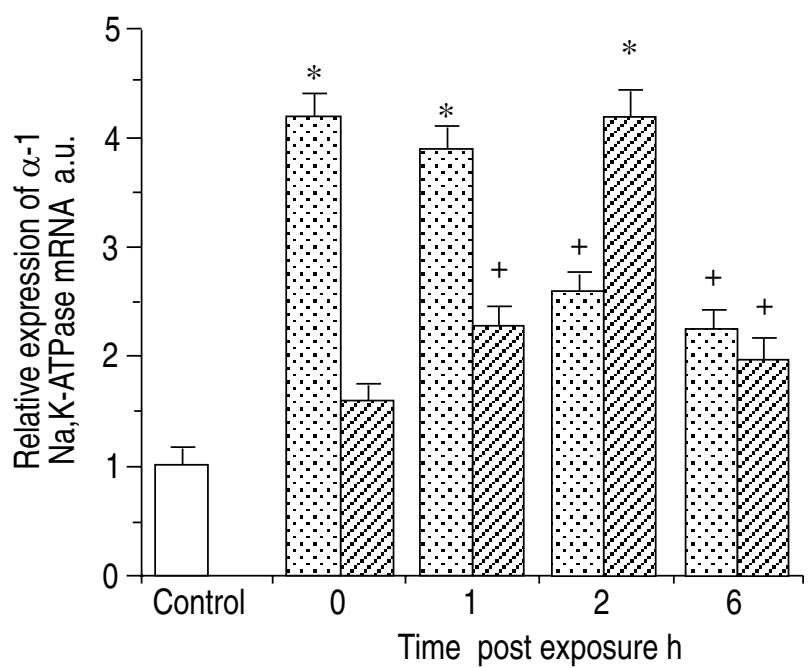

Fig. 2. - Effects of intermittent and single hyperbaric oxygen (HBO) exposure on rat lung $\mathrm{Na}, \mathrm{K}$-ATPase $\alpha-1$ steady-state mRNA transcript levels. $\alpha-1 \mathrm{Na}, \mathrm{K}-\mathrm{ATPase}$ mRNA subunit in arbitrary density units (a.u.) normalized to the 18S mRNA of the same samples is plotted for control rats (not exposed to $\mathrm{HBO}$ ), rats after a single $2.5 \mathrm{~h} \mathrm{HBO}$ exposure $(\because)$, and rats after intermittent $\mathrm{HBO}$ exposure $(\square)$ at different times post exposure. Data are presented as mean \pm SEM. +: $\mathrm{p}<0.05$; *: difference of $\mathrm{p}<0.001$ vs control. ATPase: adenosine triphosphatase; mRNA: messenger ribonucleic acid.

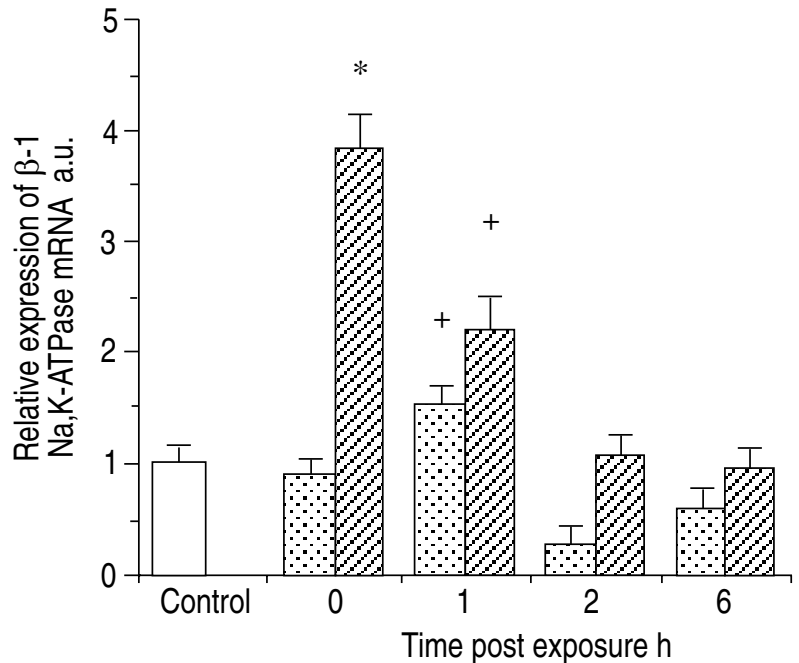

Fig. 3. - Effects of intermittent and single hyperbaric oxygen (HBO) exposure on rat lung $\beta-1 \mathrm{Na}, \mathrm{K}-\mathrm{ATPase}$ mRNA transcript levels. The relative expression of the $\beta-1 \mathrm{Na}, \mathrm{K}$-ATPase subunit in arbitrary density units (a.u.) normalized to the $18 \mathrm{~S}$ mRNA of the same samples is plotted for control rats (not exposed to HBO), rats after a single $2.5 \mathrm{~h}$ HBO exposure ( $\because \because$ ), and rats after intermittent $\mathrm{HBO}$ exposure $(\square)$ at different times post exposure. Data are presented as mean \pm SEM. +: $\mathrm{p}<0.05 ; *: \mathrm{p}<0.001$ vs control. For abbreviations see legend to figure 2 .

HBO exposure group, the Na,K-ATPase $\beta-1$ mRNA transcripts increased by $50 \%$ over control by $1 \mathrm{~h}$ and returned to control level by $2 \mathrm{~h}$.

The Na,K-ATPase hydrolytic activity increased twofold at 2 and $6 \mathrm{~h}$ following single $\mathrm{HBO}$ exposure as compared to controls (fig. 4). After intermittent HBO exposure, Na,K-ATPase activity increased by $70 \%$ at $1 \mathrm{~h}$ and then returned to control levels by $2 \mathrm{~h}$.

Immunohistochemical detection of rat $\alpha-1 \mathrm{Na}, \mathrm{K}-\mathrm{ATPase}$ protein, $2 \mathrm{~h}$ following a single $2.5 \mathrm{~h} \mathrm{HBO}$ exposure, was localized to the basolateral surface of the rat alveolar epithelium. Increased staining was observed as compared to control rat lungs, as shown in fig $5 \mathrm{a}$ and $\mathrm{b}$.

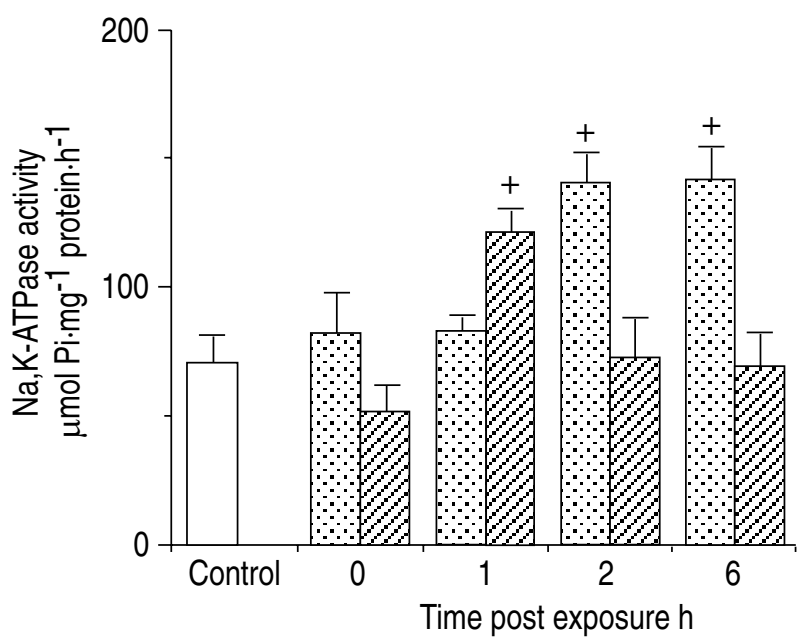

Fig. 4. - Effects of hyperbaric oxygen (HBO) on Na,K-ATPase activity in the rat lung. $\mathrm{Na}, \mathrm{K}$-ATPase hydrolytic activity measured as umoles of inorganic phosphate $(\mathrm{Pi})$ consumed $\cdot \mathrm{mg}^{-1}$ of protein per hour is plotted for control rats (not exposed to $\mathrm{HBO}$ ), rats after a single $2.5 \mathrm{~h} \mathrm{HBO}$ exposure $(\because \because)$ and rats after intermittent $\mathrm{HBO}$ exposure $(\square)$ at different times post exposure. Data are presented as mean \pm SEM. +: $\mathrm{p}<0.05$ vs control. ATPase: adenosine triphosphatase. 
a)

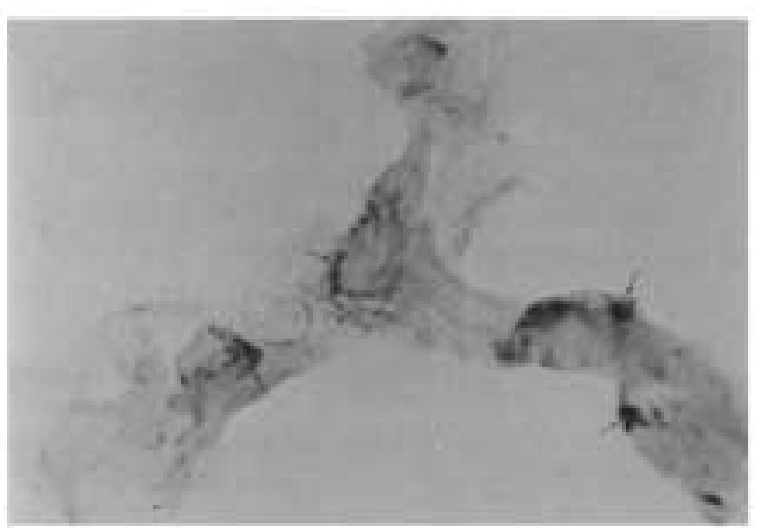

b)

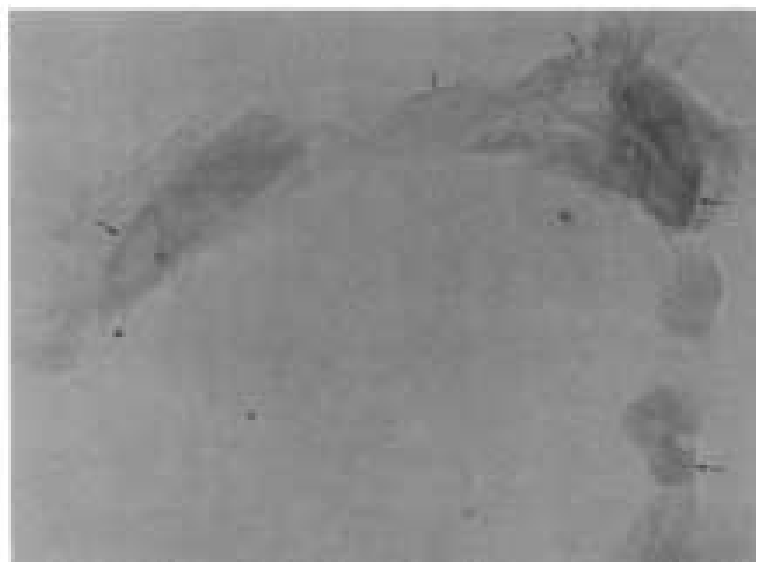

Fig. 5. - Immunohistochemical localization of the $\alpha-1 \mathrm{Na}$,K-adenosine triphosphatase (ATPase) protein (arrows) in rat lung sections: a) $2 \mathrm{~h}$ following hyperbaric oxygen (HBO $2.5 \mathrm{~h}$ ) exposure, as compared to: b) controls.

Within the limitations of the immunohistochemical detection of the $\alpha-1 \mathrm{Na}, \mathrm{K}-\mathrm{ATPase}$ protein, assuming a consistent amount of $\mathrm{Na}, \mathrm{K}-\mathrm{ATPase}$ per gold particle, a qualitative difference was demonstrable, in the $\mathrm{HBO}$ exposed rats as compared to controls, was demonstrable in all the sections examined. The photomicrographs shown were prepared from rats $2 \mathrm{~h}$ after they were exposed to a single $2.5 \mathrm{~h} \mathrm{HBO}$ exposure.

The 5 ' flanking region of the Na,K-ATPase $\alpha-1$ gene contains consensus sequences for several transcription factors, among them the activating protein-1 (AP-1) site. Thus, total RNA was isolated from the lungs of rats exposed to HBO for $2.5 \mathrm{~h}$. After 6,12 and $24 \mathrm{~h}$ of recovery significantly increased expression of jun mRNA was found by Northern blot analysis, as shown in figure $6 \mathrm{a}$ and $\mathrm{b}$.

\section{Discussion}

Exposure of Sprague-Dawley rats to $100 \%$ oxygen is fatal by $72 \mathrm{~h} \mathrm{[13].} \mathrm{Pretreatment} \mathrm{with} \mathrm{interleukin-1} \mathrm{(IL-}$ 1), endotoxin, or $85 \%$ oxygen exposure for 7 days, however, has been shown to confer protection and improve survival to subsequent $100 \%$ oxygen exposure [14-16]. Lung tolerance to hyperoxia is probably the result of upregulation of antioxidants and other protective mechanisms, such as increased clearance of oedema fluid via, among other mechanisms, enhanced lung Na,K-ATPase

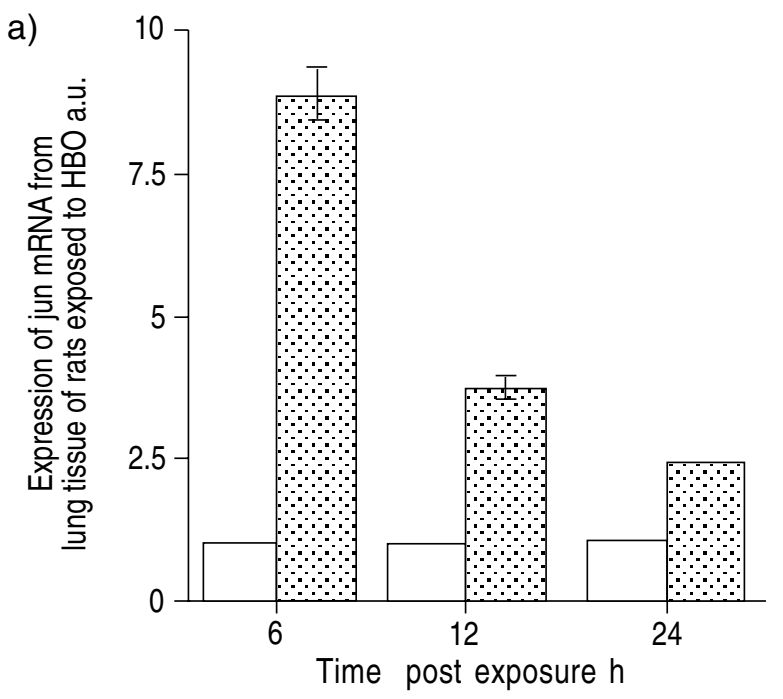

b)

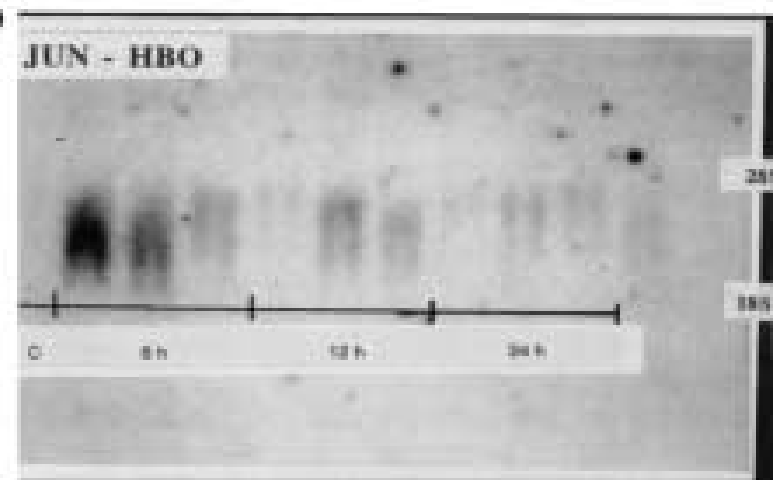

Fig. 6. - a) Effects of single hyperbaric oxygen (HBO) exposure on rat lung jun steady-state mRNA transcript levels. Relative steady state are shown for jun mRNA transcript level in arbitrary density units (a.u.) normalized to the $18 \mathrm{~S}$ rRNA of the same samples are shown for control rats (not exposed to HBO), and rats after a single $2.5 \mathrm{~h}$ HBO exposure at different times post exposure. Data are presented as mean \pm SEM. $\square$ : Control; $\because \because:$ : HBO. b) A representative autoradiogram of rat lung jun steady-state mRNA. C: control. For abbreviations see legend to figure 2 .

activity $[6,7,17]$. Other modalities, such as pretreatment with oxygen radical scavengers or delivery of antioxidants complexed to liposomes into the airways have also been shown to be protective against hyperoxia [18]. Intermittent $\mathrm{HBO}$ has also conferred protection in rats and guinea-pigs against fatal lung injury [5], suggesting that short-term HBO can be protective against oxidant injury, possibly by upregulating endogenous antioxidant protective mechanisms.

Previous reports showed that continuous HBO exposures of 5-10 h caused seizures and death [5]. Not wanting to induce pulmonary or central nervous system (CNS) toxicity, we chose HBO exposure times that would induce oxidant stress prior to causing significant lung injury. $\mathrm{HBO}$ was delivered at 2.8 ATA, similar to the treatment parameters used for $\mathrm{CO}$ intoxication and wound healing in patients.

We found that intermittent $\mathrm{HBO}$ (2.8 ATA, 100\% oxygen), three $1.5 \mathrm{~h}$ exposures, $24 \mathrm{~h}$ apart, prior to a single $2.5 \mathrm{~h}$ exposure, caused a fourfold increase in $\alpha-1$ subunit Na,K-ATPase mRNA levels. However, this upregulation occurred at $2 \mathrm{~h}$ of recovery and was not significantly 
different from the increased $\alpha-1 \mathrm{Na}, \mathrm{K}$-ATPase mRNA seen in the single exposure group. Also, HBO increased steady-state Na,K-ATPase $\alpha-1$ and $\beta-1$ mRNA transcripts in rat lung tissue after a single $2.5 \mathrm{~h}$ exposure, and in rats which, prior to the $2.5 \mathrm{~h}$ exposure, were pre-exposed for three $1.5 \mathrm{~h} \mathrm{HBO}$ at $24 \mathrm{~h}$ intervals. These findings may be due to increased message stability and/or increased transcription triggered by $\mathrm{HBO}$, which was short enough not to produce lung injury (fig. 1), but enough to increase $\mathrm{Na}, \mathrm{K}-\mathrm{ATPase}$ mRNA transcript levels (figs. 2 and 3), and Na,K-ATPase amount and function in the lung (figs. 4 and 5). Similar results were observed in another study, where $\mathrm{Na}, \mathrm{K}-\mathrm{ATPase}$ numbers and function were increased in alveolar epithelial type 2 (AT2) cells isolated from rats exposed to HBO, but there was no increase in $\mathrm{Na}, \mathrm{K}$-ATPase measured in AT2 cells isolated from rats exposed to the same hyperbaric conditions with $21 \%$ oxygen [19].

From previous studies, we expected to find that the group of animals exposed to intermittent $\mathrm{HBO}$ prior to receiving a single $\mathrm{HBO}$ exposure would have a more rapid response or have an elevated baseline $\mathrm{Na}, \mathrm{K}$-ATPase levels of mRNA transcripts and activity. However, we observed that rats exposed to single HBO had an immediate increase in $\alpha-1 \mathrm{Na}, \mathrm{K}$-ATPase mRNA transcripts, whilst the intermittent exposure rats lagged in their $\alpha-1$ Na,K-ATPase mRNA increase (figs. 2 and 3). Both groups of rats had similar increases in mRNA transcripts, as compared to controls.

A previous study showed that rats exposed to $100 \%$ oxygen for $60 \mathrm{~h}$ upregulated Na,K-ATPase in the alveolar epithelium [7]. We have previously reported that rats exposed to $85 \%$ oxygen for 7 days had increased $\mathrm{Na}, \mathrm{K}-\mathrm{ATPase}$ number and function in AT2 cells, as compared to controls, and this was associated with an increase in active $\mathrm{Na}^{+}$transport in the isolated rat lung model $[6,17]$. Possibly, in these two models, reactive oxygen species at the alveolar surface initiate a cascade of events that includes increased cytoplasmic calcium [20], cyclic adenosine monophosphate (cAMP), S6 kinases, etc. [21]. Conceivably, these second messengers induce transcription factors that may increase $\mathrm{Na}, \mathrm{K}$ ATPase subunit transcription by oxidant stress. The 5' flanking region of the rat $\mathrm{Na}, \mathrm{K}-\mathrm{ATPase}$ gene has been shown to contain multiple transcription factor binding consensus sequences, including: AP-1, stimulatory protein-1 (SP-1), and glucocorticoid response elements (GRE) $[22,23]$. We observed that the transcription factor jun is increased $6 \mathrm{~h}$ after recovery from $\mathrm{HBO}$ exposure and decreases gradually by $24 \mathrm{~h}$ of recovery (fig. 6). Possibly, this and/or other yet unknown sequences participate in the transcriptional activation of Na,K-ATPase genes during HBO-induced oxidant stress. Alternatively, HBO may have increased mRNA transcript stability.

\section{Differential Na,K-ATPase $\alpha-1$ and $\beta-1$ mRNA upregu- lation}

The timing of mRNA transcript increases of the $\mathrm{Na}, \mathrm{K}$ ATPase $\beta-1$ subunit differed from that of the $\alpha-1$ subunit expression in the HBO-exposed rat lung. Apparently, the $\beta$ subunit is affected more in the intermittent exposure group. Possibly, this differential mRNA upregulation is related to the cell's "need" for protein translation of the specific message encoded for. Although the $\alpha$ subunit is the catalytic subunit, the $\beta$ subunit protein is more stable, stored in inner cellular membranes, and has a longer half-life than the $\alpha$ subunit $[24,25]$. The $\alpha$ subunit is degraded when not bound to the $\beta$ subunit and is not stored within the cell [24]. Separation of the $\beta$ subunit from the $\alpha$ subunit irreversibly inactivates enzymatic activity [25], suggesting that the $\beta$ subunit is the rate-limiting peptide. Thus, it is possible that, following HBO exposure, stored $\beta$ subunits become available to form heterodimers with newly synthesized $\alpha$ subunits. Also, it is possible that the $\alpha$ and $\beta$ subunits are recruited from a stored pool and, following HBO exposure, are inserted into the plasma membrane independent of mRNA transcript levels. Yet another possibility is that the observed differences reflect limitations of our assay sensitivity. Our immunohistochemical analysis supports the notion that HBO does increase alveolar epithelial $\mathrm{Na}, \mathrm{K}-$ ATPase protein (fig. 5).

\section{Transcriptional activation of Na,K-ATPase}

Cloning and analysis of the 5'-flanking region of the rat $\mathrm{Na}, \mathrm{K}-\mathrm{ATPase} \alpha-1$ subunit gene revealed a transcription site 262 base pairs upstream from the translation initiation codon. A TATA-like box sequence, two SP-1, two GRE and an active transcription factor consensus binding sequence were also identified $[22,23]$. Fos and jun are leucine-zipper transcription factors that form a heterodimer and activate transcription by binding the AP-1 binding site through a 5'TGACTCA-3' sequence. We found increased expression of jun mRNA (fig. 6) from whole lung tissue homogenates from rats exposed to $\mathrm{HBO}$ for $2.5 \mathrm{~h}$ at 6,12 and $24 \mathrm{~h}$ of recovery. These results support our reasoning that transcriptionally regulated mechanisms could contribute to the observed increase in $\mathrm{Na}, \mathrm{K}-\mathrm{ATPase}$ mRNA.

\section{Mechanisms of Na,K-ATPase upregulation}

We reason that there are at least two possible mechanisms by which $\mathrm{Na}, \mathrm{K}-\mathrm{ATPase}$ is upregulated in response to oxidative stress. Firstly, the increase in activity may reflect an increase in pump number per unit plasma membrane. This can occur by the translocation or recruitment of $\mathrm{Na}, \mathrm{K}-\mathrm{ATPa} e$ pumps from the inner membranes to the plasma membrane. Precedent for this mechanism exists, in that translocation of $\mathrm{Na}, \mathrm{K}-\mathrm{ATPase}$ from inner to plasma membranes has been shown to occur in rat skeletal muscle $30 \mathrm{~min}$ after injection of insulin [26, 27]. Through translocation, the cell is able to increase Na,KATPase number and function pending synthesis of new $\mathrm{Na}, \mathrm{K}-\mathrm{ATPase}$. Secondly, it is also possible that transcriptional-translational upregulation of $\mathrm{Na}, \mathrm{K}$-ATPase increased $\mathrm{Na}, \mathrm{K}-\mathrm{ATPase}$ protein and activity in the lung.

The half-life of Na,K-ATPase in the lung has not been defined, nor how long it takes for de novo protein synthesis to occur. It is possible, therefore, that each or both of these mechanisms contribute to the upregulation 
of $\mathrm{Na}, \mathrm{K}-\mathrm{ATPase}$ following exposure of rats to $\mathrm{HBO}$. However, the short time-course under which the increase in Na,K-ATPase activity occurred in our experiments favours translocation as a plausible mechanism. Another possibility which remains is that each $\mathrm{Na}, \mathrm{K}$-ATPase pump increases activity from a basal level to a higher level. We hypothesize that an increase in message stability or transcription inducing translation of the Na,K-ATPase protein would take more time.

In summary, our results suggest that the steady-state $\mathrm{Na}, \mathrm{K}-\mathrm{ATPase} \alpha-1$ and $\beta-1 \mathrm{mRNA}$ transcripts increased, as well as $\mathrm{Na}, \mathrm{K}-\mathrm{ATPase}$ protein and function in rat lungs following both a single $2.5 \mathrm{~h}$ HBO exposure, and after three daily $1.5 \mathrm{~h}$ exposures followed by a single $2.5 \mathrm{~h}$ $\mathrm{HBO}$ exposure. Increased alveolar $\mathrm{Na}, \mathrm{K}$-ATPase activity contributes to increased active $\mathrm{Na}^{+}$transport, and to accelerated lung oedema clearance $[6,28,29]$. Restoration of alveolar epithelial permeability and increased clearance leads to reduction of oedema and may be associated with increased survival in patients with hypoxaemic respiratory failure [28-30]. Thus, HBO could offer a mode of protection against pulmonary oedema by regulating alveolar $\mathrm{Na}, \mathrm{K}$-ATPase. We reason that short-term hyperbaric hyperoxia increases $\mathrm{Na}, \mathrm{K}-\mathrm{ATPase}$ expression and function, whereas hyperbaric normoxia (2.8 ATA, 21\% oxygen) did not affect the Na,K-ATPase [19]. Further studies are necessary to elucidate the mechanisms of the oxidant stress $\mathrm{Na}, \mathrm{K}$-ATPase regulation.

Acknowledgements: The authors gratefully acknowledge H.A. Jaffe and D. Rutschman for their help with this project.

\section{References}

1. Freeman BA, Topolosky MK, Crapo JD. Hyperoxia increases oxygen radical production in rat lung homogenates. Arch Biochem Biophys 1988; 216: 477-484.

2. Nishiki K, Jamieson D, Oshino N, Chance B. $\mathrm{O}_{2}$ toxicity in the perfused rat liver and lung under hyperbaric conditions. Biochem J 1976; 160: 343-355.

3. Noda Y, McGeer PL, McGeer EG. Lipid peroxide distribution in brain and the effect of hyperbaric oxygen. $J$ Neurochem 1983; 40: 1329-1332.

4. Welty KE, Fracica PJ, Piantadosi CA, Crapo JD. Hyperbaric pulmonary oxygen toxicity. Am Rev Respir Dis 1991; 143: A727.

5. Harabin AL, Braisted JC, Flynn ET. Response of antioxidant enzymes to intermittent and continuous hyperbaric oxygen. J Appl Physiol 1990; 69: 328-335.

6. Olivera W, Ridge K, Wood LDH, Sznajer JI. Active sodium transport and alveolar epithelial $\mathrm{Na}, \mathrm{K}-\mathrm{ATPase}$ increase during subacute hyperoxia in rats. Am J Physiol 1994; 266: L577-L584.

7. Nici L, Dowin R, Gilmore-Hebert M, Jamieson J, Ingbar D. Upregulation of rat lung Na-K-ATPase during hyperoxic injury. Am J Physiol 1991; 261: L307-L314.

8. Chomczynski P, Sacchi N. Single-step method of RNA isolation by guanidine thiocynate-phenol chloroform extraction. Anal Biochem 1987; 162: 156-159.

9. Skou JC. Enzymatic basis for active $\mathrm{Na}^{+}$and $\mathrm{K}^{+}$across cell membrane. Physiol Rev 1965; 45: 596-617.

10. Fiske $\mathrm{CH}$, Subbarow Y. The colorimetric determination of phosphorous. J Biol Chem 1925; 66: 375-400.

11. Lowry OH, Rosebrough NJ, Farr AK, Randall RJ. Protein measurement with the Folin phenol reagent. J Biol Chem 1951; 193: 265-275.
12. Shyjan AW, Levenson R. Antisera specific for the alpha1, alpha-2, alpha-3, and beta subunits of the Na,K-ATPases: differential expression of alpha and beta subunits in rat tissue membranes. Biochemistry 1989; 28: 4531-4535.

13. Crapo JD, Barry BE, Foscue HA, Shelburne J. Structural and biochemical changes in rat lungs occurring during exposure to lethal and adaptive doses of oxygen. Am Rev Respir Dis 1980; 122: 123-143.

14. Rosenbaum RM, Wittner M, Lenger M. Mitochondrial and other ultrastructural changes in great alveolar cells of oxygen-adapted and poisoned rats. Lab Invest 1969; 69: 516-528.

15. Iqbal J, Clerch L, Hass M, Frank L, Massaro D. Endotoxin increases lung $\mathrm{Cu}, \mathrm{Zn}$ superoxide dismutase mRNA: $\mathrm{O}_{2}$ raises enzyme synthesis. Am J Physiol 1989; 257: L61-L64.

16. White CW, Ghezzi P, McMahon S, Dinarello CA, Repine JE. Cytokines increase rat lung antioxidant enzymes during exposure to hyperoxia. J Appl Physiol 1989; 66: 1003-1007.

17. Sznajder JI, Olivera WG, Ridge KM, Rutschman DH. Mechanisms of lung lipid clearance during hyperoxia in isolated rat lungs. Am J Respir Crit Care Med 1995; 151: 1519-1525.

18. Turrens J, Crapo JD, Freeman B. Protection against oxygen toxicity by intravenous injection of liposome-entrapped catalase and superoxide dismutase. J Clin Invest 1984; 73: 87-95.

19. Harris ZL, Ridge K, Sznajer JI. Modulation of alveolar $\mathrm{Na}, \mathrm{K}-\mathrm{ATPase}$ by hyperbaric oxygenation in rats. Am J Respir Crit Care Med 1994; 149: A59.

20. Wirtz HRW, Dobbs LG. Calcium mobilization and exocytosis after one mechanical stretch of lung epithelial cells. Science 1990; 250: 1266-1269.

21. Fanburg B, Massaro DJ, Cerutti PA, Gail DB, Berberich MA. Conference Report. Regulation of gene expression by $\mathrm{O}_{2}$ tension. Am J Physiol 1992; 262: L235-L241.

22. Yagawa Y, Kawakami K, Nagano K. Cloning and analysis of the 5'-flanking region of the rat Na,K-ATPase a-1 subunit gene. Biochim Biophys Acta 1990; 1049: 286-292.

23. Harris ZL, Gius D, Ridge K, Sukhatme V, Sznajder JI. Transcription factors increase during oxidative lung injury. Am Rev Respir Dis 1993; 147: A1005.

24. Kawamura M, Noguchi S. In: Kaplan JH, De Weer P, eds. The Sodium Pump: Structure, Mechanism and Regulation. Rockefeller Press, 1991; pp. 45-61.

25. Lescale-Matys L, Putnam D, McDonough A. Na-K-ATPase $\alpha-1$ and $\beta-1$ subunit degradation: evidence for multiple subunit specific rates. Am J Physiol 1993; 264: C538-C590.

26. Coutry N, Blot-Chabaud M, Matei P, Bonvalent JP, Farman N. Time-course of sodium-induced Na,K-ATPase recruitment in rabbit cortical collecting tubule. $A m J$ Physiol 1992; 263: C61-C68.

27. Hundal HS, Marette A, Mitsumoto Y, Ramlal T, Blostein $\mathrm{R}$, Klip A. Insulin induces translocation of the $\alpha-2$ and $\beta-1$ subunits of the $\mathrm{Na}, \mathrm{K}-\mathrm{ATP}$ ase from intracellular compartments to the plasma membrane in mammalian skeletal muscle. J Biol Chem 1992; 267: 5040-5043.

28. Matthay MA, Wiener-Kronish JP. Intact epithelial barrier function is critical for the resolution of alveolar edema in humans. Am Rev Respir Dis 1990; 142: 1250-1257.

29. O'Brodovich $\mathrm{H}$. When the alveolus is flooding, it's time to man the pumps. Am Rev Respir Dis 1990; 142: $1247-1248$.

30. Sznajder JI, Wood LDH. Beneficial effects of reducing pulmonary edema in patients with acute hypoxemic respiratory failure. Chest 1991; 100: 890-892. 